\title{
COMPARISON OF THE FREQUENCY OF POSITIVE HEARING SCREENING OUTCOMES IN SCHOOLCHILDREN FROM POLAND AND OTHER COUNTRIES OF EUROPE, CENTRAL ASIA, AND AFRICA
}

\author{
Piotr H. Skarżyński ${ }^{1,2,3}$, Adam Piłka ${ }^{1}$, Maciej Ludwikowski ${ }^{1}$ Magdalena B. Skarżyńska ${ }^{3}$ \\ ${ }^{1}$ World Hearing Center, Institute of Physiology and Pathology of Hearing, Warsaw/Kajetany, Poland \\ ${ }^{2}$ Heart Failure and Cardiac Rehabilitation Department of the Medical University of Warsaw, Warsaw, Poland \\ ${ }^{3}$ Institute of Sensory Organs, Warswa/Kajetany, Poland
}

Corresponding author: Piotr H. Skarżyński, World Hearing Center, Institute of Physiology and Pathology of Hearing, Mochnackiego 10 Str., 02-042 Warsaw, Poland, e-mail: p.skarzynski@inz.waw.pl

\begin{abstract}
Objective: Universal newborn hearing screening programs have been successfully implemented in many countries, and result in early intervention and therapy. However, there are also a significant number of schoolchildren who have hearing problems. This study presents the results of a program of hearing screening in schoolchildren, implemented in Poland and subsequently followed up in other countries in support of the European Consensus on school-age hearing screening. The aim was to compare the frequency of positive outcomes of hearing screening between the countries.
\end{abstract}

Material and methods: Screening outcomes from the following countries were compared: Poland, Moldova, Romania, Russia, Tajikistan, Kyrgyzstan, Azerbaijan, Armenia, Senegal, and the Ivory Coast. Screening was performed using the Sense Examination Platform, developed in Warsaw, Poland, by the Institute of Sensory Organs and the Institute of Physiology and Pathology of Hearing. The Platform comprises a central computer and a number of other portable computers communicating with the central database via the Internet, and can perform pure tone audiometry and other hearing, speech, and vision tests. It also records the answers to an audiological questionnaire. The test was considered to be positive when pure tone audiometry was higher than $20 \mathrm{~dB}$ HL for at least one frequency.

Results: Among children aged 6-8 years from Poland the rate of positive results was $13.9 \%$, while in children aged 12-15 years it was $8.5 \%$. From the other European countries in which 462 children were tested, positive results occurred in 62 (13.4\%). In four countries of Central Asia, positive outcomes of hearing screening were found in 216 children from 1011 tested (21.4\%). In two African countries, positive results were found in 105 children from 321 tested (32.7\%). The questionnaire surveys have shown that more than $30 \%$ of children with normal hearing have tinnitus, and the figure rises to nearly $50 \%$ in children with an abnormal result. Only $33 \%$ of children with hearing problems reported them to parents. In Poland, only $40 \%$ of children with hearing loss are under the care of a specialist, compared with only about half that number in children from Tajikistan and Moldova.

Conclusions: This study demonstrates that there are many children in primary schools who have hearing problems, and this situation may affect their education. The solution could be screening programs conducted directly in schools by trained school personnel (e.g. school nurses). The program of hearing screening in schoolchildren described here has helped to raise awareness of the importance of hearing conservation and inspired the development of new programs.

Keywords: hearing screening • school-age children • hearing loss • tinnitus • sensory organs

\section{LA COMPARACIÓN DE LOS RESULTADOS POSITIVOS DE EXÁMENES DE} AUDICIÓN DE LOS ESCOLARES EN POLONIA Y OTROS PAÍSES DE EUROPA, ASIA CENTRAL Y ÁFRICA

\section{Resumen}

Objetivos: Muchos países llevan el pograma de screening de audición de recién nacidos dando como resultado una intervención y tratamiento temprano. Pero todavía hay un gran número de niños de edad escolar con problemas de audición. Este trabajo presenta los resultados del programa de screening de audición de los escolares que fue realizado primero en Polonia y después fue continuado en otros países, para apoyar el Consenso eEuropeo sobre el screening de la audición de los escolares. El objetivo del estudio fue comparar la incidencia de los resultados positivos de screening de audición entre los países. 
Material y métodos: Fueron comparado los resultados de screening en Polonia, Moldavia, Rumania, Rusia, Tayikistán, Kirguistán, Azerbaiyán, Armenia, Senegal y Costa de Marfil. El screening se llevó a cabo utilizando el Plataforma de la Investigación de los Sentidos, que fue desarrollado en Varsovia por el Instituto de Sentidos y el Instituto de Fisiología y Patología Auditíva. EL plataforma consiste de un sistema informático central y ordenadores portátiles que transmiten datos a la base central a través de la conexión a Internet y permiten realizar audiometría tonal y otras pruebas de audición, discurso y vista. Hay también una encuesta audiológica. El resultado de la prueba es positivo cuando un umbral audiométrico es mayor que $20 \mathrm{~dB} \mathrm{HL}$ en al menos una frecuencia.

Resultados: Los resultados positivos entre los niños de 6-8 años en Polonia fue 13,9\%, mientras que en los niños de 12 a 15 años fue $8,5 \%$. En otros países europeos entre 462 niños que fueron examinado los resultados positivos se observaron en 62 niños (13,4\%). En cuatro países de Asia Central los resultados positivos de screening de audición se encontró en 216 niños de 1.011 examinados $(21,4 \%)$. En los dos países africanos resultados positivos se encontraron en 105 niños de 321 examinados $(32,7 \%)$. Las encuestas han demostrado que más del $30 \%$ de los niños con audición normal tienen el tinnitus, y la cifra se eleva a casi el 50\% en niños con el oído anormal. Sólo el 33\% de los niños con problemas de audición han informado a los padres sobre este problema. En Polonia sólo el 40\% de los niños con la pérdida auditiva están bajo el cuidado de un especialista, en comparación con alrededor de la mitad de este número de niños en Tayikistán y Moldavia.

Conclusiones: Este programa ha demostrado que un gran número de alumnos de la escuela primaria tiene problemas auditivos, que no es sólo un problema de salud, sino también de educación. La solución posible es el programa de screening realizado directamente en las escuelas por el personal escolar entrenado (por ejemplo, enfermeras escolares). El screening de audición de los escolares, que fue presentado en este trabajo, ha ayudado a crear la conciencia de la importancia de la protección auditiva y fue la inspiración para el desarrollo de nuevos programas.

\section{СРАВНЕНИЕ ЧАСТОТЫ ПОЛОЖИТЕЛЬНЫХ РЕЗУЛЬТАТОВ СКРИНИНГОВЫХ ИССЛЕДОВАНИЙ СЛУХА ДЕТЕЙ ШКОЛЬНОГО ВОЗРАСТА В ПОЛЬШЕ И В ДРУГИХ СТРАНАХ ЕВРОПЫ, ЦЕНТРАЛЬНОЙ АЗИИ И АФРИКИ}

\section{Изложение}

Цели: Программы скрининговых исследований слуха младенцев были успешно внедрены во многих странах, что привело к интервенции и терапии на ранней стадии. Однако, у значительного количества детей школьного возраста есть проблемы со слухом. В данной работе представлены результаты программы скрининговых исследований слуха детей школьного возраста, проведенной в Польше, а позже в других странах с целью поддержки Европейского консенсуса по скрининговым исследованиям слуха детей школьного возраста. Целью работы было сравнить частоту положительных результатов скрининговых исследований слуха в разных странах.

Материалы и методы: Мы сравнили результаты скрининговых исследований слуха в следующих странах: Польше, Молдавии, Румынии, России, Таджикистане, Киргизии, Азербайджане, Армении, Сенегале и Кот-д’Ивуаре. Скрининговые исследования были выполнены с помощью Платформы Исследования Органов Чувств, которая была разработана в Варшаве Институтом Органов Чувств, а также Институтом Физиологии и Патологии Слуха. Платформа состоит из главного компьютера и нескольких переносных компьютеров, связанных с центральной базой данных через интернет и позволяет выполнить тональную аудиометрию, а также другие исследования слуха, речи и зрения. Устройство также может записывать ответы на вопросы аудиологической анкеты. За положительный результат теста признается такой результат, при котором порог тональной аудиометрии больше 20 дБ HL по крайней мере на одной частоте.

Результаты: Среди 6-8-ти летних детей из Польши показатель положительных результатов составил 13,9\% процентов, а у 12-15-ти летних детей - 8,5\%. В других европейских странах, в которых было исследовано 462 ребенка, положительные результаты были замечены у 62 детей (13,4\%). В четырех странах Центральной Азии, положительные результаты скрининговых исследований слуха были замечены у 216 детей из 1011 исследованных детей (21,4\%). В двух странах Африки положительные результаты были замечены у 105 детей из 321 исследованного ребенка (32,7\%). Результаты анкеты показали, что у более $30 \%$ детей с нормальным слухом были обнаружены ушные шумы, тогда как данное количество ворастет до почти $50 \%$ у детей с проблемами со слухом. Только $33 \%$ детей с проблемами со слухом сообщили об этом своим родителям. В Польше только $40 \%$ детей с нарушениями слуха наблюдается у специалистов, в сравнении с в два раза меньшим количеством детей в Таджикистане и Молдавии.

Результаты: Результаты данной работы показывают, что у большого количества учеников начальной школы наблюдаются проблемы со слухом, что может негативно повлиять на их обучение. Решением этой проблемы могут послужить скрининговые программы, проводимые непосредственно в школах специально обученными работниками школы (напр. школьные медсестры). Программа скрининговых исследований слуха детей школьного 
возраста, описанная в данной работе, помогла обратить особое внимание на охрану слуха и стала инспирацией для разработки новых программ.

\section{PORÓWNANIE CZ̨̨STOŚCI WYNIKÓW DODATNICH BADAŃ PRZESIEWOWYCH SEUCHU DZIECI W WIEKU SZKOLNYM W POLSCE I W INNYCH KRAJACH EUROPY, AZJI CENTRALNEJ I AFRYKI}

\section{Streszczenie}

Cel: Programy badań przesiewowych słuchu u noworodków zostały z powodzeniem wdrożone w wielu krajach, co doprowadziło do wczesnej interwencji i terapii. Jednak również znaczna liczba dzieci w wieku szkolnym ma problemy ze słuchem. W niniejszej pracy przedstawiono wyniki programu badań przesiewowych wśród uczniów, realizowanego w Polsce, a następnie kontynuowanego w innych krajach, w celu wsparcia Europejskiego Konsensusu dotyczącego badań przesiewowych słuchu dzieci w wieku szkolnym. Celem pracy było porównanie częstości dodatnich wyników badań przesiewowych słuchu pomiędzy krajami.

Materiał i metody: Porównywano wyniki badań przesiewowych z następujących krajów: Polska, Mołdawia, Rumunia, Rosja, Tadżykistan, Kirgistan, Azerbejdżan, Armenia, Senegal i Wybrzeże Kości Słoniowej. Badania przesiewowe wykonywano przy użyciu Platformy Badań Zmysłów opracowanej w Warszawie, przez Instytut Narządów Zmysłów oraz Instytut Fizjologii i Patologii Słuchu. Platforma obejmuje centralny komputer i wiele przenośnych komputerów komunikujących się z centralną bazą danych przez Internet, i umożliwia wykonanie audiometrii tonalnej oraz innych badań słuchu, mowy i wzroku. Zapisuje również odpowiedzi na kwestionariusz audiologiczny. Test uznaje się za pozytywny, gdy próg audiometrii tonalnej jest większy niż $20 \mathrm{~dB}$ HL dla co najmniej jednej częstotliwości.

Wyniki: Wśród dzieci w wieku 6-8 lat z Polski wskaźnik pozytywnych wyników wyniósł 13,9\%, natomiast u dzieci w wieku 12-15 lat było to $8,5 \%$. W innych krajach europejskich, w których przebadano 462 dzieci, pozytywne wyniki wystąpiły u 62 $(13,4 \%)$. W czterech krajach Azji Środkowej, pozytywne wyniki badań przesiewowych słuchu stwierdzono u 216 dzieci z 1011 badanych (21,4\%). W dwóch krajach afrykańskich, pozytywne wyniki stwierdzono u 105 dzieci z 321 badanych (32,7\%). Badania ankietowe wykazały, że ponad $30 \%$ dzieci z normalnym słuchem ma szumy uszne, a liczba ta wzrasta do prawie $50 \%$ u dzieci z nieprawidłowym wynikiem. Tylko 33\% dzieci z problemami słuchu poinformowało o tym swoich rodziców. W Polsce tylko $40 \%$ dzieci z ubytkiem słuchu jest pod opieką specjalisty, w porównaniu do około połowy tej liczby dzieci w Tadżykistanie i Mołdawii.

Wnioski: Wyniki niniejszej pracy wskazują, że istnieje wiele dzieci w szkołach podstawowych, które mają problemy ze słuchem, a to może mieć wpływ na ich edukację. Rozwiązaniem mogą być programy przesiewowe prowadzone bezpośrednio w szkołach przez przeszkolonych pracowników szkoły (np. pielęgniarki szkolne). Program badań przesiewowych słuchu w wieku szkolnym opisany w niniejszej pracy pomógł podnieść świadomość znaczenia ochrony słuchu i był inspiracją do rozwoju nowych programów.

\section{Background}

The proper functioning of hearing, vision, and speech is the basis for social communication, and in today's society they are necessary for rapid and accurate information flow. Deficits in hearing can cause problems with receiving the information and can also impair speech development. In turn, this may prevent attendance in mainstream schools and the achievement of a full education. Therefore in many countries universal newborn hearing screening programs have been introduced [1-10]. Many children have benefited from early interventions such as cochlear implants, hearing aids, or appropriate rehabilitation management. Nevertheless, there are still a large number of school-age children with hearing disorders.

In Poland, the first studies on hearing screening in newborns were performed by Prof. Maria Goralówna (presented in 1993 at a congress in Augustow, Poland). In 1995-98, Prof. Henryk Skarżyński and co-workers undertook several studies on this area [11]. All these studies were limited to newborn screening, and resulted in the development of a universal newborn hearing screening program that is now part of the general health care system in Poland.

A key age for diagnosing communication disorders - apart from infancy and preschool - is when the child is in primary school. At this time, malfunction of the sensory organs can give rise to delays in learning, difficulties in acquiring language skills, and impaired intellectual development, all of which rely on effective communication with the environment. Early detection and diagnosis of disorders of hearing, vision, and speech, together with appropriate treatment, can promote a child's proper development and allow them to fully participate in life. Therefore, in 2001, with experience gathered from studies of newborns [2,11], the Institute of Physiology and Pathology of Hearing began performing epidemiological studies focused on schoolchildren.

The importance of detecting communication disorders was raised during the Polish Presidency of the Council of the European Union. It succeeded in drawing the attention of politicians, representatives of the Member States, and EU 
institutions to the issues surrounding disorders of hearing, vision, and speech among children, and to the consequences of not treating these disorders. Solutions were identified that might overcome the problems and allow their effects to be limited. A universal screening program for children in preschool and in school was recommended as the most effective way forward.

On the initiative of Prof. Henryk Skarżyński, in June 2011 two European scientific consensuses were signed. The first was the European Scientific Consensus on screening for hearing, vision, and speech in children of preschool and school age, a document signed by European audiologists, ophthalmologists, and speech and language therapists (the European Federation of Audiology Societies, EFAS, and the European Union of Phoniatricians, Committee of Speech Therapists, EPSCO). The second was the European Scientific Consensus on universal hearing screening for children in preschool and primary school, signed by the representatives of 27 countries gathered together in EFAS [12].

The culmination of the Polish Presidency was the signing by the EU Council, in Brussels, of the 'Conclusions on early detection and treatment of communication disorders in children, including the e-Health tools and innovative solutions' (2011/C361/04), at the meeting of the EPSCO Council on 2 December 2011 [13]. The 'Conclusions' invites representatives of the governments of the Member States to take measures for early detection and treatment of disorders of hearing, sight, and speech in children, including the implementation of screening programs and the use of the opportunities offered by modern technologies and e-health.

In Poland, the Institute of Physiology and Pathology of Hearing, in collaboration with KRUS (the Polish Agricultural Social Insurance Fund), continued their research on epidemiology of hearing loss in children and undertook hearing screening of 92876 schoolchildren [14]. The program was based on mobile devices for screening and unique systems to allow for the management of results, data collection, and quality assurance testing [14].

This model for hearing screening makes it possible to implement screening of school-age children not only in Poland, but well beyond its borders. These activities have been carried out in recent years by the World Hearing Center of the Institute of Physiology and Pathology of Hearing and the Institute of Sensory Organs. That study continues programs performed in Poland in 2008-2010 and is based on the same methodology $[14,15]$. The screening program includes work in developing countries which have basic levels of medicine. In order to ensure an appropriate organizational framework for the implementation of screening programs, an International Consortium for Hearing Screening was established. As a result of this collaboration, preliminary hearing screening has been conducted in schools in Poland, and in selected countries of Europe, Central Asia, and Africa.

The purpose of the present study is to compare the frequency of positive outcomes of hearing screening of schoolchildren in Poland and these other countries.

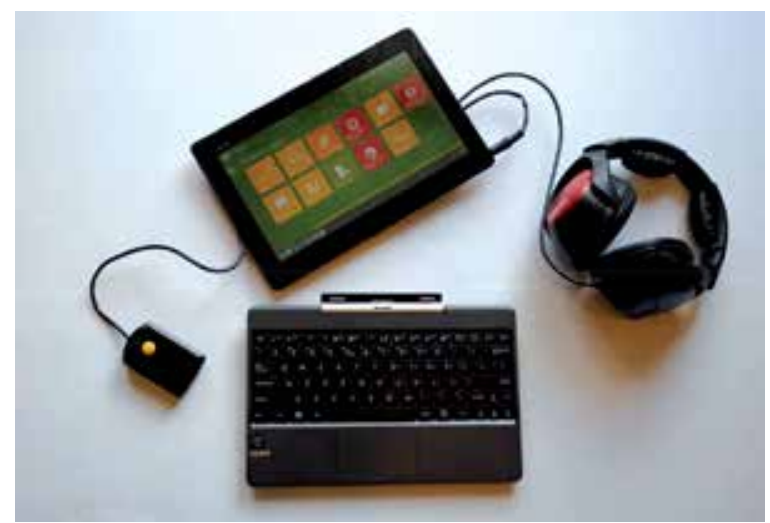

Figure 1. The Sense Examination Platform

\section{Material and methods}

\section{Methods}

Tests were performed using the Sense Examination Platform $^{\mathrm{ns}}$, a system developed by the Institute of Sensory Organs in collaboration with the Institute of Physiology and Pathology of Hearing.

The Platform is a system based on a powerful, central computer and a number of portable computers equipped with audiometric headphones and a response button. The portable computers communicate with the central database via the Internet. Each portable device is provided with software that allows a range of tests to be performed: a pure tone audiogram, audiological questionnaire, hearing screening test (' $I$ can hear ${ }^{\text {'x }}$ ), a speech screening test ('I can speak ${ }^{\text {rix }}$ ), a vision screening test ('I can see ${ }^{\mathrm{sx}}$ ), a dichotic digits test (DDT), and a gap detection test (GDT) (Figure 1).

In the present study results based on the audiogram test and the audiological questionnaire were investigated. The Sense Examination Platform is equipped with Sennheiser headphones that provide effective soundproofing of the ear from background noise. Testing was carried out in a quiet room at the school. For each child, hearing threshold was determined in the frequency range $500 \mathrm{~Hz}$ to $8000 \mathrm{~Hz}$. An anomalous (positive) result was defined as a hearing threshold higher than $20 \mathrm{~dB}$ HL for at least one frequency [16]. The test was designed to accord with IEC 606451: 2001 Audiological Equipment - Part 1: Pure-tone audiometers [17]. Children with a positive screening test were referred for otolaryngology care from a local doctor.

The audiological questionnaire documents the hearing, sight, and speech of the person under test via interviews [18]. The questionnaire has two parts, the first of which is completed by parents/carers and the second incorporates answers to questions asked of the child. Questions relate to behavior in different social environments, school marks, attention during lessons, and events that might be related to dysfunction of hearing or other senses.

An important question put to both parents/carers and the child is whether they observe tinnitus-like symptoms. If the answer is positive, further questions are asked in order to ascertain whether the tinnitus generally lasts longer 
Table 1. Age distribution of children participating in the program

\begin{tabular}{|c|c|c|c|c|c|}
\hline \multirow{2}{*}{ Country } & \multicolumn{2}{|c|}{ 6-8 years old children screened } & \multicolumn{2}{|c|}{ 12-15 years old children screened } & \multirow{2}{*}{$\begin{array}{l}\text { Total number of } \\
\text { children screened }\end{array}$} \\
\hline & $N$ & $\%$ & $\mathbf{N}$ & $\%$ & \\
\hline Poland & 71454 & $74.9 \%$ & 23957 & $25.1 \%$ & 95411 \\
\hline Moldova & 178 & $100.0 \%$ & & & 178 \\
\hline Romania & 120 & $100.0 \%$ & & & 120 \\
\hline Russia & 82 & $49.4 \%$ & 84 & $50.6 \%$ & 166 \\
\hline Tajikistan & 143 & $100.0 \%$ & & & 143 \\
\hline Kyrgyzstan & 246 & $60.3 \%$ & 162 & $39.7 \%$ & 408 \\
\hline Azerbaijan & 170 & $100.0 \%$ & & & 170 \\
\hline Armenia & 290 & $100.0 \%$ & & & 290 \\
\hline Senegal & 191 & $100.0 \%$ & & & 191 \\
\hline Ivory Coast & 130 & $100.0 \%$ & & & 130 \\
\hline Total & 73004 & $75.1 \%$ & 24203 & $24.9 \%$ & 97207 \\
\hline
\end{tabular}

or shorter than 5 minutes and what was its characteristic. There have been a few studies to date about how to measure and characterize tinnitus [19-21], but there is as yet no final agreement.

The results of screening test were sent to the main database immediately after examination, in accordance with European data safety rules. Screening tests were scheduled only at times when the risk of infection was low. For example in Poland they were performed between the beginning of March and the end of July, 2010 [14,15]. The studies in other countries were carried out in 2011-2013.

Based on the result of an initial screening in Poland, specialists of the World Hearing Center developed criteria for the following two groups of children: referral (those who require further specialist care); and prevention (the parents of the children were sent information about the need to prevent hearing disorders and about the factors that may cause the deepening of a detected hearing loss).

Statistical analyses were performed using Statistica 10.0. The prevalence of hearing loss and the results of the survey were subject to a Pearson chi-square test. A value of $p<0.05$ was considered statistically significant.

\section{Material}

Under an agreement with KRUS, screening was performed during four months of 2010 over nine regions of western Poland. There were 4,041 schools included in the program and 95,411 children were tested. The largest age group was 7 -year old children, representing $75 \%$ of all subjects. There were slightly more girls (51.4\%) than boys (48.6\%).

Such a large amount of research across the Polish provinces led to the creation of an international consortium to carry out pilot screening in various countries around the world. Hearing Screening pilot programs were initiated in Moldova, Romania, Russia, Tajikistan, Kyrgyzstan, Azerbaijan, Armenia, Senegal, and Ivory Coast and a total of
1796 school children were assessed (two groups of children: one aged $7-8$, the second $12-15$ y.o.) (Table 1 ).

The research carried out in Poland was a population-based study, and included all children aged 6-7 years in rural schools. Schools for pilot studies in other countries were selected by local coordinators. A school was chosen if a large proportion of parents agreed that their children could take part in the screening, and that it was not a special school.

\section{Results}

The outcome of hearing screening was considered positive if pure tone audiometry was higher than $20 \mathrm{~dB} \mathrm{HL}$ in at least one ear for at least one frequency. The children from first grade made up the largest material, consisting of 71454 children. Among them $13.9 \%$ of the results were positive (Table 2 and Figure 2).

Statistical analysis showed that the incidence of positive results in the pilot studies performed in children aged 6-8 years from Kyrgyzstan, Azerbaijan, Armenia, Senegal, and the Ivory Coast were significantly higher than those in the same age group in Poland. In the group of children aged 12-15 years, the number of positive results in Kyrgyzstan was significantly higher than in Poland. In both age groups, the percentage of children eligible for further specialist care was similar.

From the other European countries where 462 children were tested, positive results occurred in 62 (13.4\%). In four countries of Central Asia, positive results of hearing screening were found in 216 children from 1011 tested (21.4\%). In two African countries, positive results were found in 105 children from 321 tested (32.7\%) (Figure 3).

Of special interest, questions about tinnitus were included in the questionnaire. A positive result meant that there was at least one incidence of tinnitus persisting longer than 5 minutes, or that there was permanent tinnitus. In children 
Table 2. Participation of first graders and older children in the program

\begin{tabular}{|c|c|c|c|c|c|c|c|c|}
\hline \multirow{3}{*}{ Country } & \multicolumn{4}{|c|}{ 6-8 years old children } & \multicolumn{4}{|c|}{$12-15$ years old children } \\
\hline & \multicolumn{2}{|c|}{$\begin{array}{l}\text { Positive results of hearing } \\
\text { screening examination }\end{array}$} & \multicolumn{2}{|c|}{$\begin{array}{l}\text { Referred for } \\
\text { further testing }\end{array}$} & \multicolumn{2}{|c|}{$\begin{array}{l}\text { Positive results of hearing } \\
\text { screening examination }\end{array}$} & \multicolumn{2}{|c|}{$\begin{array}{l}\text { Referred for } \\
\text { further testing }\end{array}$} \\
\hline & $N$ & $\%$ & $\boldsymbol{N}$ & $\%$ & $N$ & $\%$ & $\boldsymbol{N}$ & $\%$ \\
\hline Poland & 9932 & $13.9 \%$ & 7370 & $74.2 \%$ & 2036 & $8.5 \%$ & 1395 & $68.5 \%$ \\
\hline Moldova & 24 & $13.4 \%$ & 17 & $70.8 \%$ & & & & \\
\hline Romania & 15 & $12.5 \%$ & 12 & $80.0 \%$ & & & & \\
\hline Russia & 13 & $15.9 \%$ & 10 & $76.9 \%$ & 10 & $11.9 \%$ & 7 & $70.0 \%$ \\
\hline Tajikistan & 34 & $23.8 \%$ & 25 & $73.5 \%$ & & & & \\
\hline Kyrgyzstan & 44 & $17.9 \%$ & 34 & $77.3 \%$ & 30 & $18.5 \%$ & 22 & $73.3 \%$ \\
\hline Azerbaijan & 39 & $23.8 \%$ & 32 & $82.1 \%$ & & & & \\
\hline Armenia & 69 & $23.8 \%$ & 44 & $63.8 \%$ & & & & \\
\hline Senegal & 57 & $29.8 \%$ & 51 & $89.5 \%$ & & & & \\
\hline Ivory Coast & 44 & $33.8 \%$ & 37 & $84.1 \%$ & & & & \\
\hline
\end{tabular}

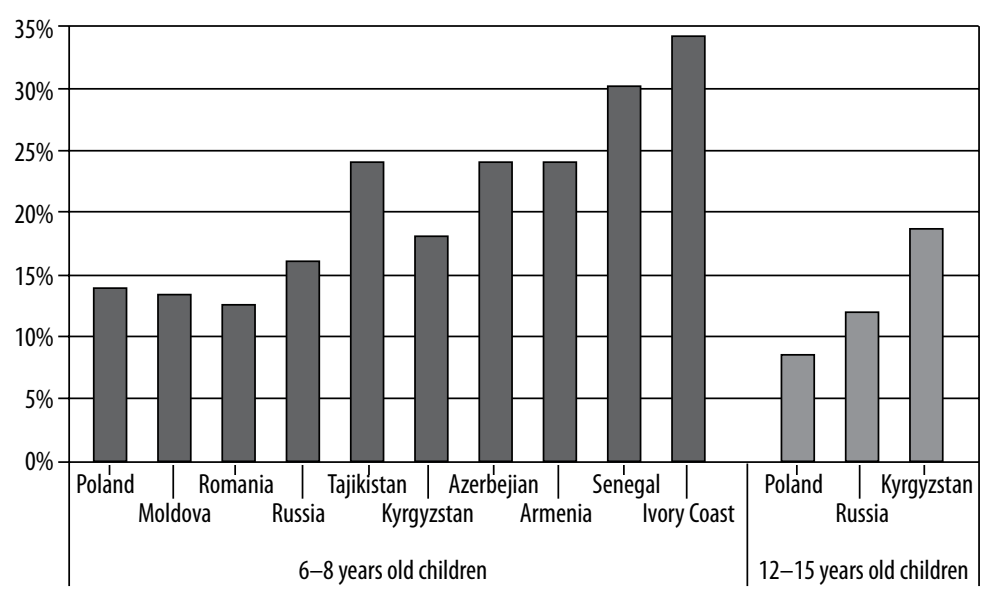

Figure 2. Age of children included in the program according to country

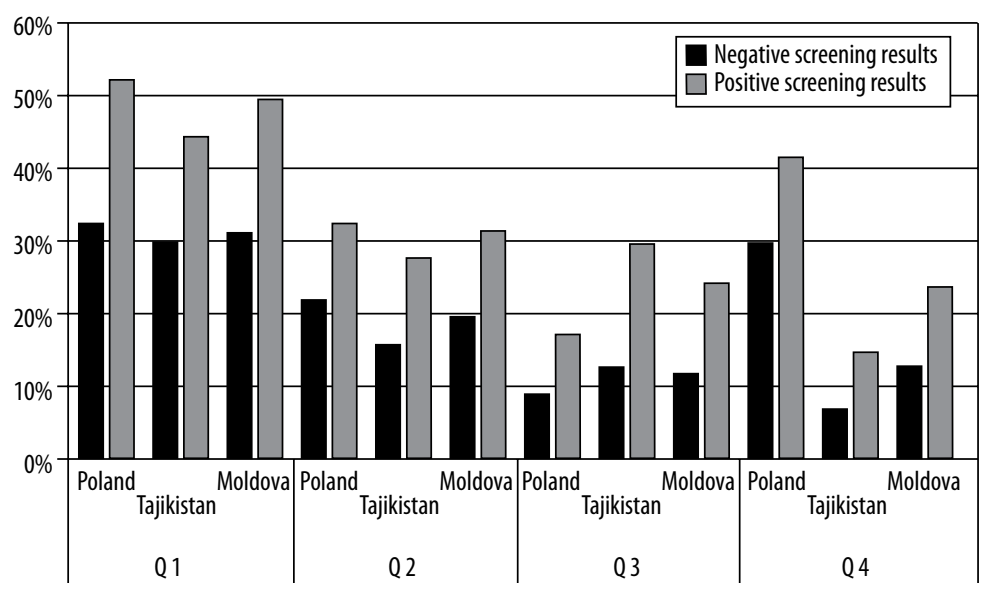

Figure 3. The results of 4 questions on the questionnaire (from Poland, Tajikistan, and Moldova) for children aged 6-8 years, according to whether the screening test was negative (black) or positive (grey). Q1: The child hears squealing/whistling noise when they are falling asleep or when the room is quiet; Q2: The child reports hearing problems; Q3: The child has poor or very poor academic performance; Q4: The child has had a previous hearing test

with a negative screening result the prevalence of tinnitus was about $30 \%$. In children with a positive screening test, there was a statistically significant increase, and the incidence of tinnitus ranged from 44 to $51.7 \%$.
Hearing problems were reported by $30 \%$ of children with a positive screening test, and of these the frequency of problems was about $10 \%$ higher than in children with negative results. 
In children with negative screening, learning problems occurred in $8 \%$ of them in Poland rising to $12 \%$ in Tajikistan. There was a statistically significant increase in the incidence of poor academic performance in those with a negative screening outcome compared to those with a positive result. In addition, for those with a positive outcome, the incidence of children with poor educational results was significantly higher for Tajikistan children compared to similar Polish children.

In Poland, $41 \%$ of children with positive screening are under the care of a specialist, while in other countries the incidence is significantly smaller (in Tajikistan only $14 \%$, in Moldavia 23\%). Noteworthy also is the awareness children had of any hearing problems which were not revealed by the screening. In Poland $29 \%$ were aware of having a hearing problem, while in other countries the percentage ranged from 6 to $12 \%$.

\section{Discussion}

The results of the present study have shown that many schoolchildren have hearing problems. In a large population, 13 to $17 \%$ of the younger children (6-8 years old) had a positive screening test result. In Tajikistan, Azerbaijan, Armenia, Senegal, and the Ivory Coast the proportion of positive results was over $20 \%$, and in African countries some $33 \%$ of children had an abnormal result. In the three countries where screening was performed on 12-15 year olds, there was a slightly lower incidence of positive screening outcomes. Only in Kyrgyzstan was there was a slight increase in the incidence of positive results in older children.

Other international studies have shown that, at comparable ages, the percentage of positive results ranges from a few percent to more than $30 \%$. The large spread is related to different screening protocols and different eligibility criteria for an abnormal result. In 2003, Skarżyński et al. conducted screening for frequencies of 1000, 2000, and $4000 \mathrm{~Hz}$, and with a criterion of $20 \mathrm{~dB}$ HL saw positive results of more than $16 \%$ [22]. Results of studies conducted in Iran have shown that $10 \%$ of children aged 7-8 years old may have a hearing problem. The smaller incidence of hearing loss may be due to the frequency range tested - the Iranian tests were carried out over a narrower range
(500 to $4000 \mathrm{~Hz}$ ) [23]. In a study by Niskar et al. [24] nearly $15 \%$ of children aged $6-11$ years had abnormal screening test results.

Pilot screening done in the European countries (Moldova, Romania, Russia) gave a similar percentage of abnormal results as the examinations carried out in Poland. Studies In Asian countries have demonstrated that the incidence of positive results is a few percent higher than in Poland. This might be related to the fact that the study here was conducted in the winter-spring period, which increases the incidence of temporary hearing loss [25-27]. In a pilot study conducted in African countries (Senegal and the Ivory Coast), 1 child in 3 had a hearing problem. Similar results were obtained in studies conducted in Nigeria by Oyewumi et al. [28], where more than half the children had low-frequency deficits related to conductive hearing loss. Finally, it must be noted that the differences in the frequency of hearing loss, especially in countries where only a pilot study were conducted, could be affected by the choice of schools in which the survey was conducted.

The questionnaire shows that tinnitus appears to be a widespread problem in children. The percentage of positive responses to questions related to tinnitus grows with age. Parents/carers of children referred for further diagnostic tests could choose any suitable clinic, so the authors did not have access to follow-up information about each subject. However, in the children that presented to the Institute of Physiology and Pathology of Hearing, and its ancillary units and cooperative centers, it was noted that many children had problems that had been developing for a number of years without being diagnosed, including serious ones such as congenital cholesteatoma.

\section{Conclusions}

This study has demonstrated that there are many children in primary schools who have hearing problems, and this situation may affect their education. The solution could be screening programs conducted directly in schools by trained school personnel (e.g. school nurses). The program of hearing screening in schoolchildren described here has helped raise awareness of the importance of hearing conservation and has inspired the development of new programs.

\section{References:}

1. Watkin P, Baldwin M. The longitudinal follow up of a universal neonatal hearing screen: the implications for confirming deafness in childhood. Int J Audiol, 2012; 51(7): 519-28.

2. Skarżyński H, Senderski A, Mueller-Malesinska M, Kochanek K, Ratynska J. Program of early identification of hearing loss in newborns in Poland. International Congress Series, 2003; 1240: 269-71

3. Patel H, Feldman M. Universal newborn hearing screening. Paediatr Child Health, 2011; 16(5): 301-10.

4. Burke MJ, Shenton RC, Taylor MJ. The economics of screening infants at risk of hearing impairment: an international analysis. Int J Pediatr Otorhinolaryngol, 2012; 76(2): 212-8.
5. Tanon-Anoh MJ, Sanogo-Gone D, Kouassi KB. Newborn hearing screening in a developing country: Results of a pilot study in Abidjan, Côte d'Ivoire. Int J Pediatr Otorhinolaryngol, 2010; 74: 188-91.

6. Ahmad A, Mohamad I, Mansor S, Daud MK, Sidek D. Outcome of a newborn hearing screening program in a tertiary hospital in Malaysia: the first five years. Ann Saudi Med, 2011; 31(1): 24-8.

7. Dantas MB, Anjos CA, Camboim ED, Pimentel MC. Results of a neonatal hearing screening program in Maceió. Braz J Otorhinolaryngol, 2009; 75(1): 58-63. 
8. Nelson HD, Bougatsos C, Nygren P. Universal Newborn Hearing Screening: Systematic Review to Update the 2001 U.S. Preventive Services Task Force Recommendation. Rockville, MD: Agency for Healthcare Research and Quality; 2008.

9. Uloziene I, Grandori F. The European project AHEAD II on newborn hearing screening. International Congress Series, 2003; 1240: 329-32.

10. Garabli H, Genc GA, Kayikci MEK, Turkyilmaz MD, Ozturk B, Karabulut E, Korkmaz A, Belgin E. Hearing screening protocols of babies with hearing loss risk factors in Turkey. Int Adv Otol, 2010; 6(2): 216-22.

11. Mueller-Malesinska M, Skarżyński H, Oltarzewski M, Szymborski J, Ratynska J. Project of the countrywide data collecting system for neonatal hearing screening programme in Poland. Scand Audiol Suppl, 2001; 52: 197-8.

12. Skarżyński H, Piotrowska A, Szaflik J, Luxon L, Zehnhoff-Dinnesen A, Kaufmann-Meyer M et al. European consensus statement on hearing, vision, and speech screening in pre-school and school-age children. J Hear Sci, 2011; 1(2): 89-90.

13. Skarżyński H, Piotrowska A, Kamyk P, Czupryniak A, Saniewska-Kilim A, Włodarczyk A et al. EU Council Conclusion on early detection and treatment of communication disorders in children, including the use of e-health tools and innovative solutions. J Hear Sci, 2012; 2(1): 49-50.

14. Skarżyński H, Kochanek K, Senderski A, Skarżyński PH, Ludwikowski M, Kopaczewski M, Bruski L. Organization of the hearing screening examinations in Polish schools in rural areas and small towns. Cochlear Implants Int, 2010; 11(Suppl.1): 143-7.

15. Skarżyński PH, Kochanek K, Skarżyński H, Senderski A, Wysocki J, Szkielkowska A et al. Hearing Screening Program in School Age-children in Western Poland. Journal of International Advanced Otology, 2011; 7(2): 194-200.

16. Jerger J, Jerger S. Measurement of hearing in adults. In: Paparella MM, Shumrick DA (eds.). Otolaryngology ( $\left.2^{\text {nd }} e d\right)$. Philadelphia: WB Saunders, 1980, p. 1226.

17. Rozporządzenie Ministra Gospodarki, Pracy i Polityki Społecznej z dnia 30 stycznia 2004 r. w sprawie wymagań metrologicznych, którym powinny odpowiadać audiometry tonowe (Dz. U. Nr 24 poz. 214 dn. 20.02.2004) [in Polish].
18. Skarżyński H, Rogowski M, Bartnik G, Fabijańska A: Organization of tinnitus management in Poland. Acta Otolaryngol, 2000; 120(2): 225-6.

19. Barros Coelho C, Ganz Sanchez T, Tyler RS. Tinnitus in children and associated risk factors. Prog Brain Res, 2007; 166: $179-91$.

20. Møller AR. Tinnitus: presence and future. Prog Brain Res, 2007; 166: 3-16.

21. ilgen C, Sezer B, Kirazli T, Gunbay T. Tinnitus in temporomandibular disorders: electrophysiological aspects. Int Adv Otol, 2010; 6(2): 167-72.

22. Skarżyński H, Czyżewski A, Senderski A, Kochanek K. "I can hear": a system for universal hearing screening in school age children. Organization and first results. International Congress Series, 2003; 1240: 325-7.

23. arafraz M, Ahmadi K. A practical screening model for hearing loss in Iranian school-aged children. World J Pediatr, 2009; 5(1): 46-50.

24. Niskar AS, Kieszak SM, Holmes A, Esteban E, Rubin C, Brody DJ. Prevalence of hearing loss among children 6 to 19 years of age: the Third National Health and Nutrition Examination Survey. JAMA, 1998; 279(14): 1071-5.

25. Toner JG, Mains B. Pneumatic otoscopy and tympanometry in the detection of middle ear effusion, Clin Otolaryngol Allied Sci, 1990, 15(2): 121-3.

26. Monasta L, Ronfani L, Marchetti F, Montico M, Vecchi Brumatti L, Bavcar A et al. Burden of disease caused by otitis media: systematic review and global estimates. PLoS One, 2012; 7(4): e36226.

27. Georgalas C, Xenellis J, Davilis D, Tzangaroulakis A, Ferekidis E. Screening for hearing loss and middle-ear effusion in schoolage children, using transient evoked otoacoustic emissions: a feasibility study. J Laryngol Otol, 2008; 122: 1299-304.

28. Oyewumi AM, Adejumo OR. An investigation of hearing loss among school age children through audiological assessment in Ibadan, Oyo State, Nigeria. Elementary Education Online, 2011; 10(1): 1-11. 